\title{
Prediction Equation of Body Weight of Amazonian Manatee (Trichechus inunguis) Calves in Captivity Using Biometry
}

\author{
Pierina Mendoza ${ }^{1}$, Darwin Loja ${ }^{2}$, Rony Riveros ${ }^{1}$, Carlos Vilchez ${ }^{1}$ \\ ${ }^{1}$ Universidad Nacional Agraria la Molina, Lima, Perú; ${ }^{2}$ Universidad Nacional de la Amazonía Peruana, Iquitos, Perú
}

Correspondence to: Pierina Mendoza, mend.yeng.pieri@outlook.com

Keywords: Amazonian Manatee (Trichechus inunguis), Biometric Measurements, Body Weight, Weight

Prediction, Correlation

Received: January 19, 2017 Accepted: May 23, $2017 \quad$ Published: May 26, 2017

Copyright @ 2017 by authors and Scientific Research Publishing Inc.

This work is licensed under the Creative Commons Attribution International License (CC BY 4.0).

http://creativecommons.org/licenses/by/4.0/

\section{(c) (i) Open Access}

\section{ABSTRACT}

The objective of the study was to determine a prediction equation of body weight of Amazonian manatee calves in captivity using their biometry. It was conducted out with 7 calves (4 males and 3 females) of approximately 8 months of age and average body weight of $29.94 \pm$ $0.055 \mathrm{~kg}$, arranged in pools of sufficient size. Biometry and weighing were performed periodically, with the following measurements: body weight (BW), total curved length (TCL), total length (TL), circumference (CIR), fin width (FW), tail width (TW) and peduncle (PED). Data were subjected to Pearson correlation analysis and linear regression, using the statistical software IBM SPSS 24.0. The results showed a significant correlation $(P<0.05)$ between BW and TCL, TL, FW, TW, CIR and PED. Six linear simple regression equations were generated with relation to $\mathrm{BW}$, using as predictor variables those that showed positive correlation. The CIR equation independent variable had the highest correlation coefficient and less error estimate $\left(R^{2}=0.855, R_{a j}^{2}=0.852\right)$. In addition, three linear multiple regression equations of BW were calculated using the predictor variables previously analyzed by Person correlation analysis. The equation that used all biometric measurements (TCL, TL, FW, TW, CIR and PED) had the highest coefficient of determination and the lowest estimation error to predict BW. In conclusion, the biometric measurements of TCL, TL, FW, TW, CIR and PED showed a high correlation with the BW and can be used as predictive variables of BW of manatee calves, as they are easy to be measured.

\section{INTRODUCTION}

The Amazonian manatee, Trichechus inunguis (Natterer, 1883), is the smallest sirenian and the only 
one able to completely live in fresh water [1-3]. The Sirenia order is the only order of aquatic mammal's survivors that are exclusively herbivorous [4]. This animal is an endemic species of the Amazon basin, occupying water bodies in Brazil, Colombia, Ecuador and Peru [1, 3, 5-7], being reported in the latter mainly in rivers within Loreto region $[2,8,9]$.

The IUCN (International Union for Conservation of Nature) and Supreme Decree No. 004-2014MINAGRI categorize this species as vulnerable [10] and are included in Appendix I of CITES (The Convention on International Trade in Endangered Species of Wild Fauna and Flora) [11-13]. Currently, the Amazonian manatee is considered "Protected Amazonian Species" under the Regulation of Fishery of the Peruvian Amazon (Ministerial Resolution No. 147-2001-PE) [14] and categorized as "in danger of extinction at nationwide level" (Supreme Decree No. 034-2004-AG) [15]. The research work on this species is scarce because there are no tools that facilitate its management and conservation.

The dangers that face this species are poaching for consumption, the capture of live animals for exhibition or kept as pets as well as the degradation and pollution of their habitat $[8,16,17]$. The importance of conserving this species is its ecological role as biological control of aquatic plants, contributing to fertilization water and plankton production, and so be a kind of high ecological value [3]. Therefore, it is important to generate rescue and rehabilitation centers for this species, taking into account that the growth and development have to approximate to the performance of the animal in its natural habitat. For this reason is useful have a valid and easy to apply tools (i.e. predictor equations, weight/length ratios, body condition index, etc.) which are necessary in monitoring captive or semi-captive animals for the purpose of having an animal status indicator and improve the conditions (nutritional, environmental, structural, ethological, etc.) for its rehabilitation.

The body size is strongly correlated with many aspects of the life history of mammals, one of the most important traits of an individual and to a large extent, determines the strength and type of interactions between species $[18,19]$. Body length/weight ratio is widely used to monitor the growth and condition factor of several animal species [20-22]. Furthermore, the use of other biometrics such as curvilinear length and circumference of the body are also important tools in the estimation of body weight in predictive models, such as the seals [23-25].

In the case of the Amazonian manatee, the weight/length ratio was calculated only for calves up to three months of age $[26,27]$. Nonlinear growth models for this species have been studied using body length information from captive animals. The offered diet and implemented management can affect the characteristics of animal growth, whereby was suggested that there may be some difference between growth equations for captive animals concerning free living animals [28, 29].

Having the tool to predict the body weight of animals using biometric measures could facilitate and improve the management of these animals in captivity, also reducing the effects of stress caused by the manipulation of the animal for weighing.

The objective of the present study was to evaluate the sensitivity of the biometric measurements of the Amazonian manatee as predictors of body weight, and to generate high reliability prediction equations to facilitate the monitoring and management of the growth of this species under captivity conditions.

\section{MATERIALS AND METHODS}

The present study was performed with a total of seven calves of Amazonian manatee under captive conditions ( 4 males and 3 females); individuals belonging to the program of rescue of Aquatic Mammals of the Amazonian Rescue Center in the city of Iquitos-Peru. The animals were on average with each other apparent ages 8 months and body weight of $29.94 \pm 0.055 \mathrm{~kg}$. During the study animals were arranged in pools of sufficient size, provided shade, filter system and water renewal. Daily water temperature monitoring activities (greater than or equal to $23^{\circ} \mathrm{C}$ ) were carried out and the food supply was given in several servings per day with a dairy substitute (dairy formula used by the Rescue Center).

The weights and biometry of the calves were performed individually and periodically for 84 days. The biometric data was taken with a flexible measuring tape of $1.5 \mathrm{~m}$ with $1 \mathrm{~cm}$ of minimum unit and the body 
weight (BW) with an electronic balance of $200 \mathrm{~kg}$ of capacity and $+/-1 \mathrm{~g}$ of sensitivity, and the following variables were recorded: Total Curved Length (TCL), measure of length from the anterior cephalous-nasal end to the posterior end of the caudal fin, considering the curved perimeter of the body, defined by the dorsal line; Total length (TL), longitudinal measurement of the anterior cephalous-nasal end to the posterior end of the caudal fin, considering the projection of a straight line parallel to the vertebral column; Circumference (CIR), perimeter measurement of the abdominal circumference, similar to an imaginary transverse section at the navel section; width of fin (WF), referred to the largest segment of the pectoral fin; tail width (TW), measurement of the largest segment of the caudal fin; peduncle (PED), measurement of the perimeter circumference between the union of the body with the caudal fin.

Biometric data measurements and weight were subjected to Pearson correlation analysis and linear regression, using the statistical program SPSS 24.0. Using the same statistical program, biometric measurements (independent variables) of high correlation with respect to BW (dependent variable) were submitted to linear regression analysis, from which weight prediction equations were generated for each independent variable. In addition, three weight prediction equations using independent variables were calculated as follows: Equation (1) all independent variables with positive significant correlation, Equation (2) independent variables with coefficient of determination greater than 0.60 and Equation (3) coefficient variables with coefficient of determination greater than 0.80 .

\section{RESULTS AND DISCUSSION}

Data obtained during the evaluation are presented in Table 1. In the correlation analysis, it was found the following correlations of biometric measurements with BW: total curved length (0.910), total length (0.815), circumference $(0.924)$, fin width $(0.448)$, tail width $(0.789)$ and peduncle (0.829); showed significant positive correlations $(P<0.05)$ between BW and total curved length (TCL), total length (TL), fin width (FW), tail width (TW), circumference (CIR) and peduncle (PED) (Table 2).

When performing the linear regression between the biometric measurements and the $\mathrm{BW}$, the following prediction equations were obtained: $\mathrm{BW}=89.172 * \mathrm{TCL}-78.072\left(R^{2}=0.829, R_{a j}^{2}=0.825\right)$ (Figure 1);

Table 1. Mean, standard deviation, maximum and minimum of data collected in the biometry of calves of Amazonian manatee (Trichechus inunguis) in captivity.

\begin{tabular}{cccc}
\hline Measure & Mean \pm SD & Min & Max \\
\hline BW & $32.86 \pm 4.83$ & 23.70 & 44.00 \\
TL & $1.18 \pm 0.05$ & 1.10 & 1.18 \\
TCL & $1.24 \pm 0.05$ & 1.17 & 1.35 \\
FW & $0.09 \pm 0.01$ & 0.08 & 0.10 \\
TW & $0.3 \pm 0.02$ & 0.26 & 0.34 \\
CIR & $0.85 \pm 0.05$ & 0.77 & 0.94 \\
PED & $0.48 \pm 0.04$ & 0.38 & 0.55 \\
\hline
\end{tabular}

Table 2. Table of correlation coefficients of biometric measures with the body weight $(\mathrm{N}=58)$ of calves of Amazonian manatee (Trichechus inunguis) in captivity.

\begin{tabular}{cccccccc}
\hline & & TL & TCL & FW & TW & CIR & PED \\
\hline \multirow{3}{*}{ BW } & Pearson Correlation & $0.815^{* *}$ & $0.910^{* *}$ & $0.448^{* *}$ & $0.789^{* *}$ & $0.924^{* *}$ & $0.829^{* *}$ \\
& Sig (2-tailed) & 0.000 & 0.000 & 0.000 & 0.000 & 0.000 & 0.000 \\
$\mathrm{~N}$ & 58 & 58 & 58 & 58 & 58 & 58 \\
\hline
\end{tabular}


$\mathrm{BW}=80.100 * \mathrm{TL}-61.325\left(R^{2}=0.663, \quad R_{a j}^{2}=0.657\right)($ Figure 2$) ; \quad \mathrm{BW}=95.313 * \mathrm{CIR}-47.995 \quad\left(R^{2}=\right.$ $\left.0.855, R_{a j}^{2}=0.852\right)$ (Figure 3); $\mathrm{BW}=338.461 * \mathrm{FW}-2.556\left(R^{2}=0.201, R_{a j}^{2}=0.187\right)$ (Figure 4$)$;

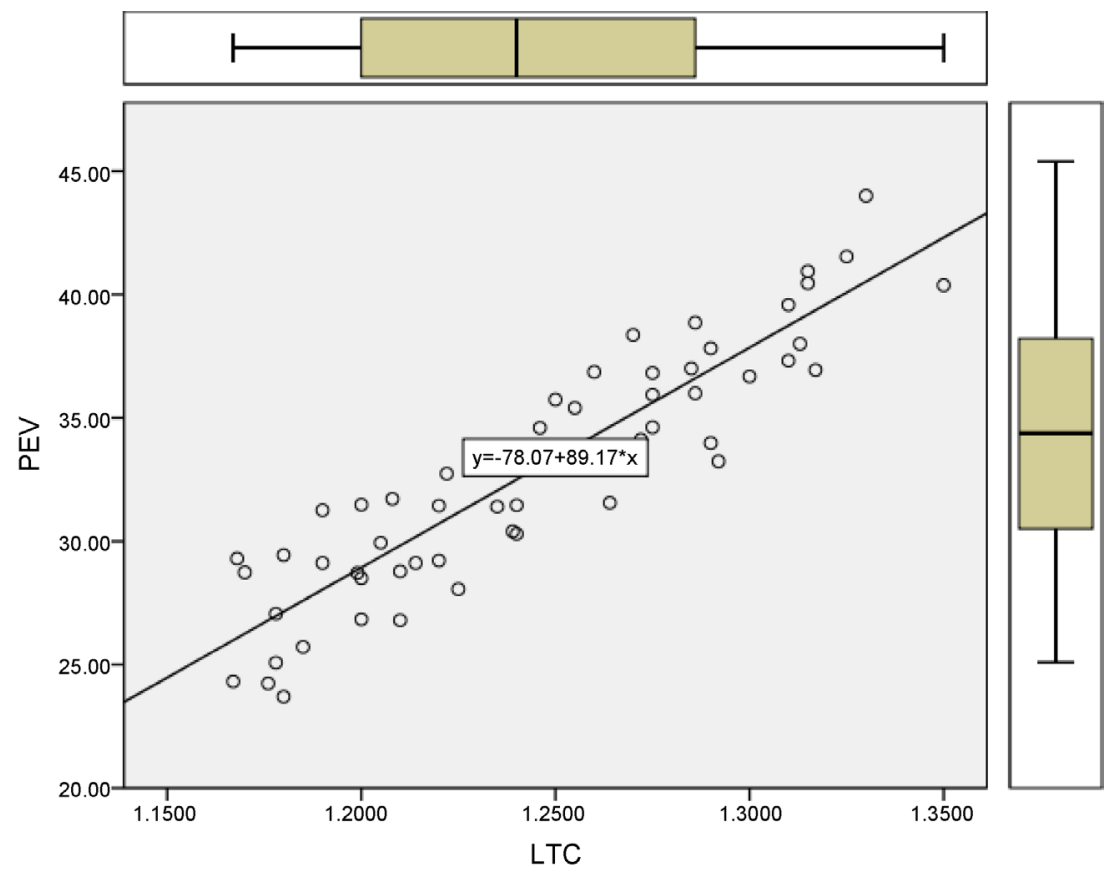

Figure 1. Scatterplot of linear regression body weight-total curved length $(\mathrm{N}=58)$ of calves of Amazonian manatee (Trichechus inunguis) in captivity.

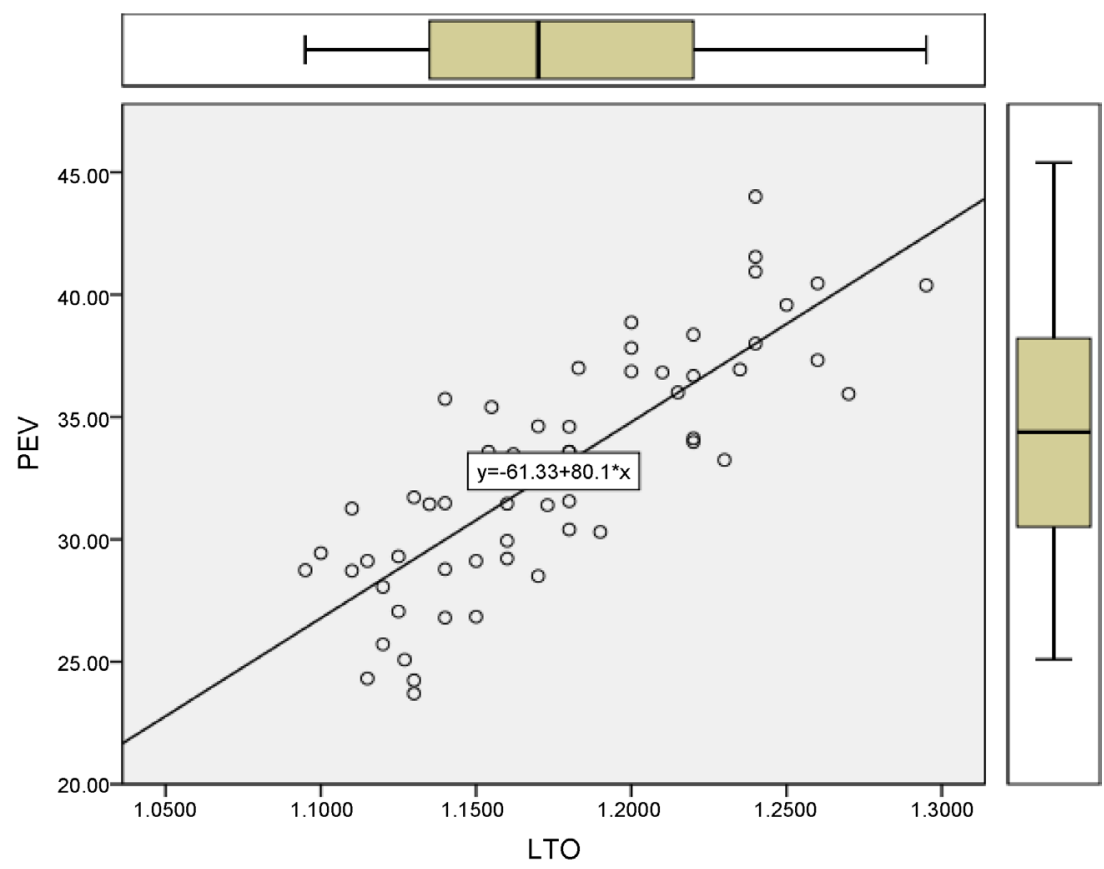

Figure 2. Scatterplot of linear regression body weight-total length $(\mathrm{N}=58)$ of calves of Amazonian manatee (Trichechus inunguis) in captivity. 


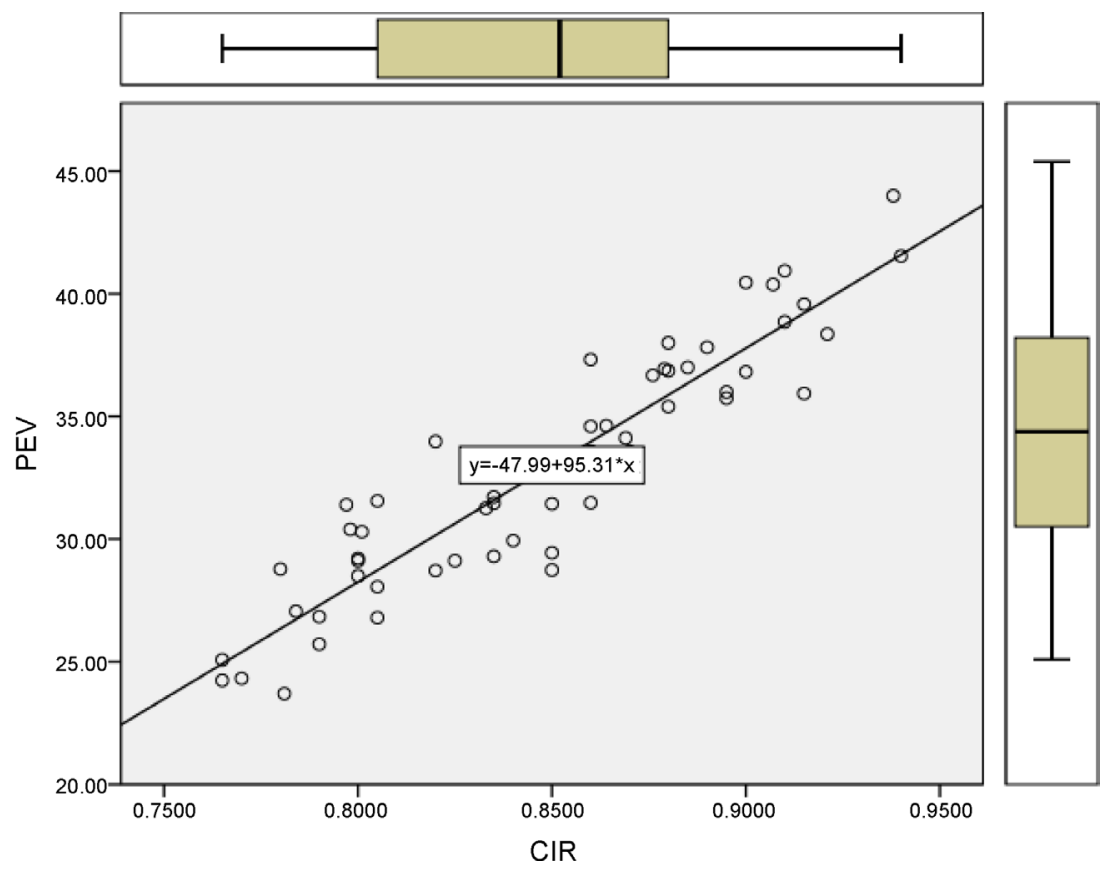

Figure 3. Scatterplot of linear regression body weight-circumference $(\mathrm{N}=58)$ of calves of Amazonian manatee (Trichechus inunguis) in captivity.

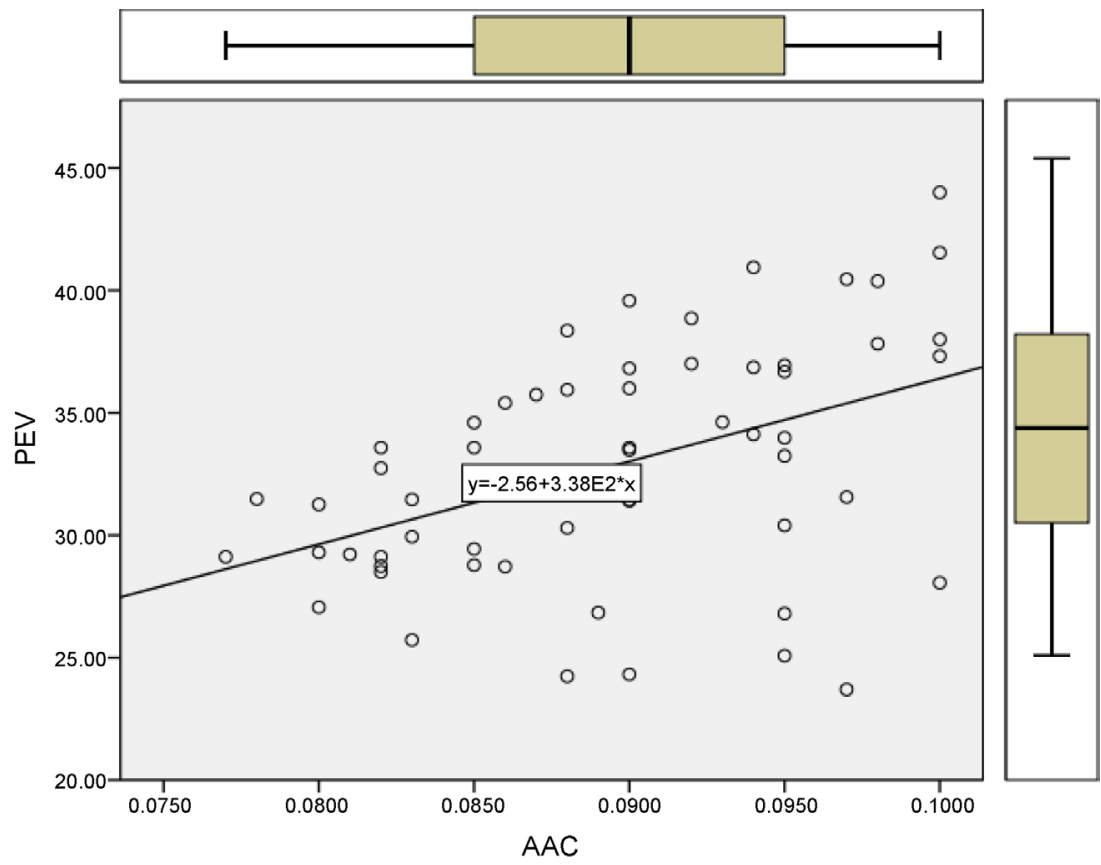

Figure 4. Scatterplot of linear regression body weight-fin width $(\mathrm{N}=58)$ of calves of Amazonian manatee (Trichechus inunguis) in captivity.

$\mathrm{BW}=209.925 * \mathrm{TW}-29.857\left(R^{2}=0.622, \quad R_{a j}^{2}=0.615\right)($ Figure 5$)$; and $\mathrm{BW}=99.977 * \mathrm{PED}-14.801$ $\left(R^{2}=0.688, R_{a j}^{2}=0.682\right)$ (Figure 6), of which the estimation errors were: $2.02,2.83,1.86,4.35,2.99$, and 


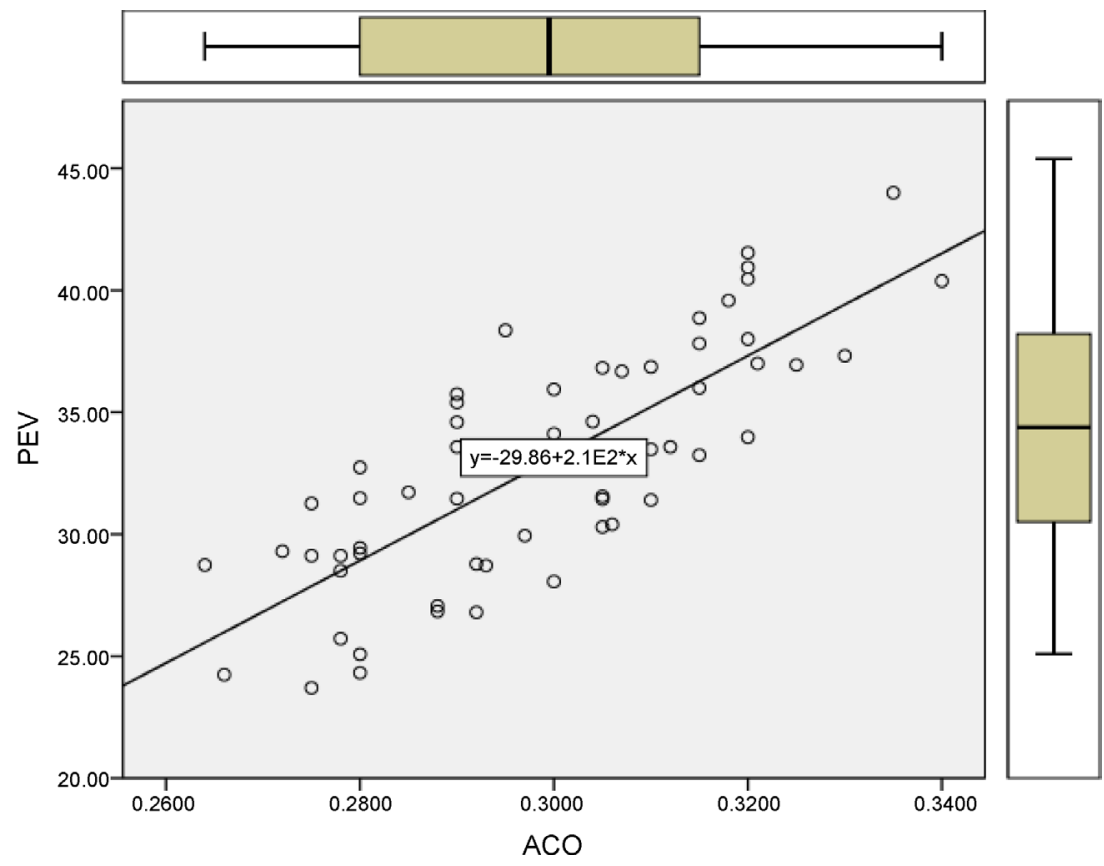

Figure 5. Scatterplot of linear regression body weight-tail width $(\mathrm{N}=58)$ of calves of Amazonian manatee (Trichechus inunguis) in captivity.

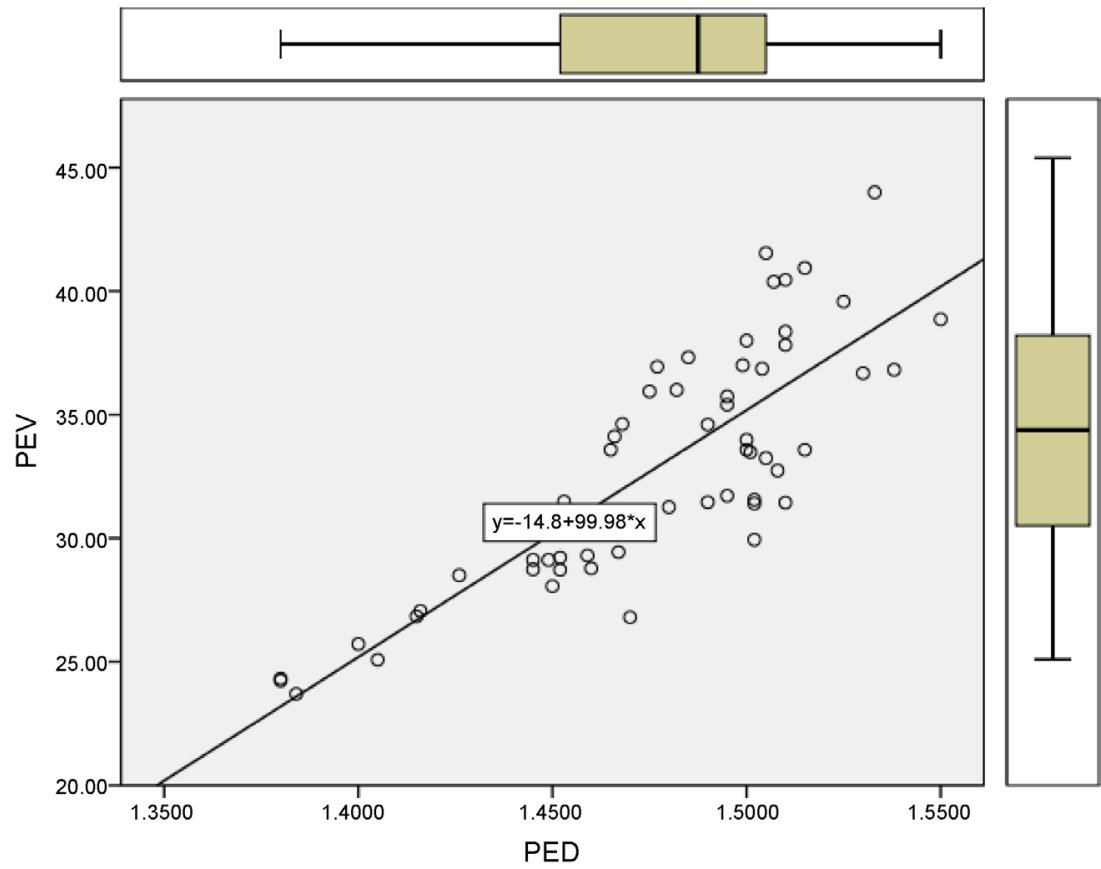

Figure 6. Scatterplot of linear regression body weight-peduncle $(\mathrm{N}=58$ ) of calves of Amazonian manatee (Trichechus inunguis) in captivity.

2.72 , respectively.

According to Rose (1994) [3], the total curved length is not a reliable variable because individuals 
with the same total length may have different curvilinear lengths depending on their nutritional status. However, in this study the total curved length was the second variable with the highest coefficient of determination with respect to body weight; which is consistent with that described by Colares (2002) [28] and Vergara-Parente et al. (2010) [30], who concluded that the total curved length is an important measure to describe the growth of manatees. The close relationship between this parameter and the body weight is evidenced by the high coefficient of correlation and determination in the linear regression, being a variable of great utility for the prediction of body weight.

Total length has been widely used in predicting body mass, body volume and growth curve in Amazonian manatees. In this regard, most animal species show a regression coefficient weight/length, about 3 [31], which has been evident in several aquatic mammals [32-35] including the Amazonian manatee reporting a regression coefficient of 3.122 [27] and 4 [26]. However, the regression coefficient obtained in the present study was higher $(b=80.1)$ than previously reported. This difference could be due to the fact that in the present work the data were analyzed in the scale of $\mathrm{Kg} / \mathrm{m}$, whereas in the previous works worked on scales of $\mathrm{Kg} / \mathrm{cm}$. Furthermore, in the case of Amaral et al. (2010) [27] used 91 data of manatees of different age ranges and total length $(73.5-261 \mathrm{~cm})$ and body weight $(7.8-363 \mathrm{~kg})$, in comparison with the present work that we analyzed 58 data of manatees of similar ages and weights, with ranges of total length $(1.10-1.18 \mathrm{~m})$ and body weight $(23.7-44 \mathrm{~kg})$, leading to a more homogeneous group of animals; and in the study by Rosas et al. (2001) [26] animals up to 3 months of age was analyzed. It is known that during the first year of life, most mammalian species gain more length, and only after weaning longitudinal growth increases in proportion to the weight and the regression coefficient tends to approach 3 [26]. With the results obtained in the present study suggests that the animals in the studied age ( $8-9$ months) have a greater development.

Abdominal circumference has been little used in manatees; however, there are studies such as Amaral et al. (2010) [27] in which the weight ratio was analyzed, overall length and maximum circumference by linear multiple regression and body volume calculated using data from these variables. The measure of abdominal circumference has been mostly used in Pinnipeds [36], thus a study of Steller sea lions, concluded that there is a significant relationship between body weight, length and girth; in addition to obtaining a multiple regression equation that allows to estimate the body weight from measures of length and circumference. This is in line with what was found in this study, in which abdominal circumference showed the highest correlation coefficient $(0.924)$ with respect to weight and its regression equation with body weight was the highest coefficient of determination $\left(R^{2}=0.855, R_{a j}^{2}=0.852\right)$, this allowed to calculate the Equation (3), summarized in the use of the variables girth and total length.

Measurements of fin width, tail width and peduncle have been used mostly for periodic monitoring of captive animals, but studies that use these variables as predictors of body weight could not be found. However, in this study the variables of FW, TW and PED showed high correlation coefficients $(0.448$, $0.789,0.829)$ with respect to body weight and their coefficients of determination of the variables TW and PED were also high $\left(R^{2}=0.622, R_{a j}^{2}=0.615\right.$ and $\left.R^{2}=0.688, R_{a j}^{2}=0.682\right)$.

In addition, we calculated three equations for prediction of body weight, Equation (1) was performed using all biometric measurements (TCL, TL, FW, TW, CIR and PED), in Equation (2) used biometric measurements LT, TW, CIR and PED $\left(R^{2}>0.6\right)$ and Equation (3) comprises biometric measures TCL and CIR $\left(R^{2}>0.8\right)$; whose results were as follows:

$$
\begin{gathered}
\mathrm{BW}=(47.177 * \mathrm{TCL})-(2.804 * \mathrm{TL})-(63.198 * \mathrm{FW})+(23.091 * \mathrm{TW})+(48.250 * \mathrm{CIR}) \\
+(13.025 * \mathrm{PED})-70.912 \quad\left(R^{2}=0.968, R_{a j}^{2}=0.965\right) . \\
\mathrm{BW}=(39.983 * \mathrm{TCL})+(0.237 * \mathrm{TL})+(9.441 * \mathrm{TW})+(49.929 * \mathrm{CIR}) \\
\quad+(16.959 * \mathrm{PED})-70.419 \quad\left(R^{2}=0.966, R_{a j}^{2}=0.963\right) \\
\mathrm{BW}=(48.252 * \mathrm{TCL})+(56.841 * \mathrm{CIR})-75.385 \quad\left(R^{2}=0.958, R_{a j}^{2}=0.957\right)
\end{gathered}
$$


Of these the estimation errors are: $0.91,0.93$ and 1.01 , respectively.

By comparing the three body weight prediction equations obtained, all of them have high determination coefficients, ensuring the reliability of all equations. Equation (1) was the equation of the highest coefficient of determination and lower estimation error to predict body weight $\left(R^{2}=0.968, R_{a j}^{2}=0.965 ; 0.91\right)$. Equation (3) is of similar utility to the other equations, allowing the estimation of body weight with only two variables (TCL and CIR), facilitating the management of Amazonian manatee in rescue centers.

In conclusion, the biometric measurements of TCL, TL, FW, TW, CIR and PED showed a high correlation with the BW of manatee and can be used as predictive variables of the body weight, being easy to measure. We suggest new studies of prediction of BW using biometrics, with animals of similar age to the present study and with more data.

\section{ACKNOWLEDGEMENTS}

To the Amazon Rescue Center, Area of Aquatic Mammals (CREA, Iquitos-Peru). Work done with funding from the 6th Undergraduate Thesis Grant Competition (2016) of La Molina National Agrarian University, Faculty of Animal Husbandry.

\section{REFERENCES}

1. Best, R.C. (1984) Trichechus inunguis, vulgo Peixe-Boi. Ciência Hoje, 2, 56-73.

2. Husar, S. (1977) Trichechus inunguis. The American Society of Mammalogists, 72, 1-4.

3. Rosas, F.C.W. (1994) Biology, Conservation and Status of the Amazonian Manatee Trichechus inunguis. Mammal Review, 24, 49-59. https://doi.org/10.1111/j.1365-2907.1994.tb00134.x

4. Sousa, I.K., et al. (2016) Variáveis hematológicas e bioquímicas de peixe-boi da Amazônia (Trichechus inungui) jovens. Pesquisa Veterinária Brasileira, 36, 869-873. https://doi.org/10.1590/s0100-736x2016000900013

5. Domning, D. (1981) Manatees of the Amazon. Sea Frontiers, 18-23.

6. Timm, R., Albuja, L. and Clauson, B. (1986) Ecology, Distribution, Harvest, and Conservation of the Amazonian Manatee Trichechus inunguis in Ecuador. Biotropica, 18, 150-156. https://doi.org/10.2307/2388757

7. Rosas, F.C.W. (1991) Peixe-boi da Amazonia Trichechus inunguis (Natterer, 1883). In: Capozzo, H.L. and JunRn, M., Eds., Estado de Conservación de los Mamíferos Marinos del Atlántico Sudoccidental, United Nations Environment Programme, Nairobi, Informes y Estudios del Programa de Mares Regionales del PNUMA, 138, 178-181.

8. Reeves, R.R., Leatherwood, S., Jefferson, T.A., Barbara, E. and Henningsen, T. (2007) Amazonian Manatees, Trichechus inunguis, in Peru: Distribution, Exploitation, and Conservation Status. Interciencia, 21, 246-254.

9. Soini, P. (1992) Evaluación preliminar de la vaca marina (Trichechus inunguis). RN Pacaya-Samiria: Estaciónbiológica 1979-1994, 35, 369-372.

10. IUCN (2016) IUCN Red List of Threatened Animals. IUCN, Gland, Switzerland and Cambridge, UK.

11. Soini, P., Sicchar, L., Gil, G., Fachìn, A., Pezo, R. and Chumbe, M. (1996) Una evaluación de la faunasilvestre y su aprovechamiento de la Reserva Nacional Pacaya Samiria, Perú. DocumentoTécnico No 24. IIAP, Iquitos, 64.

12. Silva, J. and Montes, D. (2014) Conocimientos, conservación y avistamiento del manatí amazónico (Trichechus inunguis), según los pobladores de la cuenca del río Ucayali (Loreto, Perú), 32-38.

13. MINAM (2014) Especies de Fauna Silvestre Peruana en los apendices de la CITES, (CoP 16), 65.

14. Resolución Ministerial No 147-2001-PE (2001) Aprueban el Reglamento de Ordenamiento Pesquero de la Amazonía Peruana, 5.

15. Decreto Supremo No 034-2004-AG (2007) Aprueban categorización de especies amenazadas de fauna silvestre y 
prohíben su caza, captura, tenencia, transporte o exportación con fines comerciales, 4 .

16. Hacon, S., et al. (2008) An Overview of Mercury Contamination Research in the Amazon Basin with an Emphasis on Brazil. Cadernos de Saúde Pública, 24, 1479-1492. https://doi.org/10.1590/S0102-311X2008000700003

17. Soto, A. (2007) Caza del manatí amazónico en la Reserva Nacional Pacaya Samiria. Perú. Centro de Datos para la Conservación, Universidad Nacional Agraria La Molina, 23.

18. Rudolf, V.H.W. (2012) Seasonal Shifts in Predator Body Size Diversity and Trophic Interactions in Size-Structured Predator-Prey Systems. Journal of Animal Ecology, 81, 524-532.

https://doi.org/10.1111/j.1365-2656.2011.01935.x

19. Castelblanco-Martínez, D.N., Morales-Vela, B. and Padilla-Saldívar, J.A. (2014) Using Craniometrical Predictors to Infer Body Size of Antillean manatees. Mammalia, 78, 109-115.

https://doi.org/10.1515/mammalia-2012-0136

20. Santos, E.P. (1978) Dinâmica de Populações aplicada à pesca e piscicultura. Editora da Universidade de São Paulo, São Paulo, 129.

21. De Mello, F.T., Vidal, N., Gonzalez-Bergonzoni, I. and Iglesias, C. (2009) Length-Weight Relationships of Eight Fish Species from the Lower Section of the Uruguay River (Río Negro, Uruguay). Journal of Applied Ichthyolo$g y, 25,128-129$. https://doi.org/10.1111/j.1439-0426.2008.01155.x

22. Pinheiro, M.A.A. and Fiscarelli, A.G. (2009) Length-Weight Relationship and Condition Factor of the Mangrove Crab Ucides cordatus (Linnaeus, 1763) (Crustacea, Brachyura, Ucididae). Brazilian Archives of Biology and Technology, 52, 397-406. https://doi.org/10.1590/S1516-89132009000200017

23. Castellini, M.A. and Calkins, D.G. (1993) Mass Estimates Using Body Morphology in Steller Sea Lions. Marine Mammal Science, 9, 48-54. https://doi.org/10.1111/j.1748-7692.1993.tb00425.x

24. Ireland, D., Garrott, R.A., Rotella, J. and Banfield, J. (2006) Development and Application of a Mass-Estimation Method for Weddell Seals. Marine Mammal Science, 22, 361-378. https://doi.org/10.1111/j.1748-7692.2006.00039.x

25. de Bruyn, P.J.N., Bester, M.N., Carlini, A.R. and Oosthuizen, W.C. (2009) How to Weigh an Elephant Seal with One Finger: A Simple Three Dimensional Photogrammetric Application. Aquatic Biology, 5, 31-39. https://doi.org/10.3354/ab00135

26. Rosas, F.C.W., da Silva, V.M.F., Sousa-Lima, R.S., d'Affonseca Neto, J.A. and Mattos, G.E. (2001) Adoption and Growth of a Captive Amazonian Manatee (Trichechus inunguis) Calf. Abstract Book of the 14th Biennial Conference on the Biology of Marine Mammals, Vancouver, 28 November-3 December 2001, Society of Marine Mammalogy, Vancouver, 183.

27. Amaral, R.S., Da Silva, V.M.F. and Rosas, F.C.W. (2010) Body Weight/Length Relationship and Mass Estimation Using Morphometric Measurements in Amazonian Manatees Trichechus inunguis (Mammalia: Sirenia). Marine Biodiversity Records, 3, 1-4.

28. Colares, F.A.P. (2002) Estudo de modelos não lineares de crescimento em peixe-boi marinho Trichechus manatus manatus e peixe-boi amazônico Trichechus inunguis (Mammalia: Sirenia) em cativeiro. Tese de Doutorado, Universidade Federal de Minas Gerais, Belo Horizonte.

29. Albuquerque Jr., D.P. (2003) Descrição histológica do tecido ósseo do domo timpânico, estimativa de idade e crescimento em cativeiro do peixe-boi da Amazônia Trichechus inunguis (Natterer 1883) Mammalia, Sirenia. Dissertação de Mestrado, Universidade Federal do Amazonas, Manaus.

30. Vergara-Parente, J., Parente, C., Marmontel, M., Carlos Ramos Silva, J. and Bezerra Sa, F. (2010) Growth Curve of Free-Ranging Trichechus inunguis. Biota Neotropica, 10, 8-11.

https://doi.org/10.1590/s1676-06032010000300009 
31. Santos, E.P. (1978) Dinamica de populacoes aplicadaàpesca e piscicultura. Editora da Universidade de São Paulo, Sao Paulo, 129 p.

32. Odell, D.K., Forrester, D.J. and Asper, E.D. (1978) A Preliminary Analysis of Organs Weights and Sexual Maturity in the West Indian Manatee (Trichechus manatus). Proceedings of the 1 st Workshop on the West Indian Manatee in Florida, Orlando, 27-29 March 1978, Florida Department of Natural Resources, Orlando, 52-65.

33. Trites, A.W. and Pauly, D. (1998) Estimating Mean Body Masses of Marine Mammals from Maximum Body Lengths. Canadian Journal of Zoology, 76, 886-896. https://doi.org/10.1139/z97-252

34. Rosas, F.C.W., Rocha, C.S., Mattos, G.E. and Lazzarini, S.M. (2009) Bodyweight-Length Relationships in Giant Otters (Pteronura brasiliensis) (Carnivora, Mustelidae). Brazilian Archives of Biology and Technology, 52, 587591. https://doi.org/10.1590/S1516-89132009000300010

35. Adulyanukosol, K., Prasittipornkul, C., Man-Anansap, S. and Boukaew, P. (2007) Stranding Records of Dugong (Dugong dugon) in Thailand. Proceedings of the 4th International Symposium on SEASTAR 2000 and Asian Bio-Logging Science, Phuket, 15-17 December 2007, Kyoto University, Phuket, 51-57.

36. Waite, J.N. and Mellish, J.A.E. (2009) Inter- and Intra-Researcher Variation in Measurement of Morphometrics on Steller Sea Lions (Eumetopias jubatus). Polar Biology, 32, 1221-1225.

https://doi.org/10.1007/s00300-009-0649-7

\section{Scientific Research Publishing}

\section{Submit or recommend next manuscript to SCIRP and we will provide best service for you:}

Accepting pre-submission inquiries through Email, Facebook, LinkedIn, Twitter, etc.

A wide selection of journals (inclusive of 9 subjects, more than 200 journals)

Providing 24-hour high-quality service

User-friendly online submission system

Fair and swift peer-review system

Efficient typesetting and proofreading procedure

Display of the result of downloads and visits, as well as the number of cited articles

Maximum dissemination of your research work

Submit your manuscript at: http://papersubmission.scirp.org/

Or contact ns@scirp.org 